\title{
Problems and Constraints Faced by Farmers in Financing and Marketing of Agricultural Produce in India
}

\author{
Gangu Naidu Mandala ${ }^{1, *}$, Pallawi Baldeo Sangode', S. Anjani Devi², \\ Venkata Ramakrishna Rao Gandreti ${ }^{3}$ \\ ${ }^{1}$ Symbiosis Institute of Business Management, Symbiosis International Deemed to be University, India \\ ${ }^{2}$ GITAM Institute of Management, GITAM Deemed to be University, Visakhapatnam, India \\ ${ }^{3}$ Vignan’s Institute of Engineering for Women, Visakhapatnam, India
}

Received January 14, 2021; Revised February 7, 2021; Accepted March 23, 2021

\section{Cite This Paper in the following Citation Styles}

(a): [1] Gangu Naidu Mandala, Pallawi Baldeo Sangode, S. Anjani Devi, Venkata Ramakrishna Rao Gandreti , "Problems and Constraints Faced by Farmers in Financing and Marketing of Agricultural Produce in India," Universal Journal of Accounting and Finance, Vol. 9, No. 2, pp. 139 - 144, 2021. DOI: 10.13189/ujaf.2021.090201.

(b): Gangu Naidu Mandala, Pallawi Baldeo Sangode, S. Anjani Devi, Venkata Ramakrishna Rao Gandreti (2021). Problems and Constraints Faced by Farmers in Financing and Marketing of Agricultural Produce in India. Universal Journal of Accounting and Finance, 9(2), 139 - 144. DOI: 10.13189/ujaf.2021.090201.

Copyright@2021 by authors, all rights reserved. Authors agree that this article remains permanently open access under the terms of the Creative Commons Attribution License 4.0 International License

\begin{abstract}
Purpose: In this study, the main aim is to know farmers' problems in the agricultural sector. Food products are the primary good to ensure the quality of life and health. In the world, many countries are depending on the agricultural sector and farmers are the backbone of the economy. Design/methodology/approach: In this study, the main aim is to find what are the challenges faced by the farmers in Andhra Pradesh State. The present paper attempts to spell out some of the constraints like production, and marketing, and finance-related problems faced by the farmers. Primary data were collected from the farmers to investigate the aim and applied a convenient sample technique to collect opinions from the respondent. Findings: To find out production, marketing, and finance-related problems have been faced by the farmers. This study helps to encourage farmers to produce more goods and to increase productivity. Originality/value: It was concluded that a spellbinding report utilizing essential information would be fitting to explore the destinations. The essential information was gathered from the farmers by utilizing a meeting plan explicitly intended for the reason. Most extreme consideration was taken to give essential explanations in vernacular to empower the respondents to reply as precisely as conceivable with no uncertainty.
\end{abstract}

Keywords Agricultural, Economy, Farmer, Financing, Marketing and Production

\section{Introduction}

India is an agricultural nation. Farming and its unified exercises go about as principal wellspring of vocation for over $80 \%$ populace of provincial India. It gives work to roughly $52 \%$ of work. Its commitment to Gross Domestic item (GDP) is between 14 to $15 \%$. It says, "With the end goal of this Policy, the term 'FARMER' will allude to an individual effectively occupied with the financial or potentially business movement of developing harvests and delivering other essential agricultural wares and will incorporate all agricultural operational holders, cultivators, agricultural workers, tenant farmers.

Chahal, S.S. and Kataria, P [1] India is relied upon to accomplish the driven objective of multiplying ranch pay by 2022. Ramkishen, Y. [2] The agribusiness area in India is relied upon to produce better force in the following not many years because of expanded interest in agricultural framework, for example, water system offices, warehousing and cold stockpiling. Besides, the 
developing utilization of hereditarily altered harvests will probably improve the yield for Indian farmers. India is relied upon to act naturally adequate in heartbeats in the coming not many years because of purposeful exertion of researchers to get early developing assortments of heartbeats and the expansion in the least help cost.

During the last one and a half-decade, a few difficulties have surfaced in Indian agribusiness which is getting increasingly more extreme with the progression of time. This identifies with the production of yield, skill, value and manageability. The greatest test is to turn around the sharp decrease in the development pace of the horticulture area experienced after the mid-1990s. Kumari, M., Meena, L.K. and Singh [3] The rate of development has been down on agri-business growth, which shows that capital pay in agriculture falls. This is viewed as the main consideration for enormous scope rustic pain and a huge number of self-destructive passing by farmers in different pieces of the nation.

Another greatest test is to guarantee the practical utilization of common assets. While the requirement for quickening agricultural development is self-evident, the characteristic asset base in the nation is contracting. There are additionally indications of corruption of land and overexploitation of water in the nation.

Rajesh, R. and Sundaresan, R. [4] The situation calls for improving the intensity of Indian farming which requires improvement in effectiveness in agricultural creation, advertising, transport and so on. There is a solid inclination in the nation that mediation in food markets has profited just agriculturally reformist areas. The downpour took care of and dry land agribusiness locales have been disregarded. Addisu Karafo [5] There is likewise genuine worry about practicality and eventual fate of more modest size possessions which comprise the greater part of farmers in the nation. The current situation with an inauspicious image of horticulture in the nation has come about because of a few elements/reasons. A.D. Siyoum [6] The premier is absent of a clear approach to agribusiness for quite a while. The nation didn't change institutional instruments and administrative structure to establish a climate favourable for agricultural development and which was expected to conform to changes in home-grown and worldwide climate. This relates specially to support private areas in yield markets and seed markets. The subsequent explanation is disregard of foundation and redirection of assets to egalitarian measures. A third explanation is a log jam in innovation arriving at possible district and debilitating of expansion framework for dispersal of innovation. Except if uncommon changes are actualized in the farming areas it would not be conceivable to restore yield development on a feasible premise and alleviate provincial pain.

M. Kassie, P. Zikhali, K. Manjur, S. [7] Agricultural improvement is fundamental not exclusively to accomplish independence in food grains at the state level yet in addition to guaranteeing family food security and to acquire value dissemination of pay and abundance bringing about an extreme decrease of the destitution level Indeed, high financial development will have no significance for the majority of individuals living in country zones except if horticulture is renewed. Ramesh, S.V [8] Agribusiness in Andhra Pradesh is plagued with various unfavourable attributes, for example, declining complete cultivable region according to a shortage of cultivable land, low efficiency per unit of work in the majority of the areas, power of little and minor farmer families, hazard avoidance because of creation by inhabitants and agricultural workers under uncertain conditions, immense occasional varieties and presence of a huge level of convention adoring farmers Ateyah Mohammad Alawneh [9].

\section{Statement of the Problem}

Promoting agricultural items have been representing a major issue for farmers. The farmers, who produce crops, battle a great deal to bring them up. They furrow and tilt the land, seed the plants, water assets, clean them, and pack the items fit to be taken to the business sectors available to be purchased. Indeed, even at the hour of delivering the yields and at the hour of selling them they face a ton of obstacles and hindrances, for example, the impedance of representatives and agents, absence of protection office, absence of money, the significant expense of inputs, storehouses and shipping issues. In the market the farmers are cheated by the specialists the buys like charging the merchandise less, gauging the items in uneven machines, etc. Consequently, the farmers face various issues structure the underlying phase of creation to work the offer of the items on the lookout. And all these are intertwined and at last, have a profound effect on agricultural advertising. Thus, horticulture as an occupation gets unbeneficial and in this manner, unviable.

\section{Objectives of the Study}

(1) To study what challenges have been faced by the farmers in Andhra Pradesh State in India

(2) To suggest solutions to overcome the challenges faced by farmers in farming.

\section{Hypothesis}

H0 There is no significance difference between Demographics and challenges faced by the farmers in Andhra Pradesh. 


\section{Database and Methodology}

It was concluded that a spellbinding report utilizing essential information would be fitting to explore the destinations. The essential information was gathered from the farmers by utilizing a meeting plan explicitly intended for the reason. Most extreme consideration was taken to give essential explanations in vernacular to empower the respondents to reply as precisely as conceivable with no uncertainty. The topped off-timetable has been completely checked and guaranteed as respects the accuracy and consistency of information. The auxiliary information has been gotten from different optional sources like papers, magazines, diaries, books, websites of statistical abstracts of Andhra Pradesh. Reserve Bank of India, Ministry of Agriculture, Agricultural insights initially, Directorate of financial aspects and measurements, and from different institutional libraries. Andhra Pradesh State was taken as an example territory to examine the primary unbiased and 250 examples were taken as the test size and applied advantageous example strategy to gather feelings from the respondents.

\section{Methodology}

The information drawn from the different sources was exposed to factual treatment utilizing the fitting instruments. The information is broken down utilizing SPSS programming and on account of factual tests, all the speculation is tried at a 5\% importance level.

The following statistical tools have been used to analyse the collected data:

- Simple Percentage Method

- Chi-square Method

\section{Results and Discussion}

Table 1. Age

\begin{tabular}{|c|c|c|}
\hline \multicolumn{3}{|c|}{ Age } \\
\hline Classification & No. of Respondents & Percentage \\
\hline Below 30 years & 29 & 11.6 \\
\hline 31 years-45 years & 73 & 29.4 \\
\hline 46 years to 60 years & 106 & 42.2 \\
\hline Above 60 years & 42 & 16.8 \\
\hline Total & 250 & 100 \\
\hline
\end{tabular}

Source: Investigation

The above table:01 indicates farmers age groups, in this study $42.2 \%$ of respondents belong to 45 years to 60 years' age groups and $29.4 \%$ and $16.8 \%$ of respondents are belongs to 31 years to 45 years and above 60 years respectively. Here we can understand above 35 years' age farmers have been working in the agricultural sector.
Table 2. Relationship between Age and problems faced by the farmers

\begin{tabular}{|c|c|c|c|}
\hline $\begin{array}{c}\text { Problems Faced by the } \\
\text { Farmers }\end{array}$ & $X^{2}$ Value & P -Value & $\begin{array}{c}\text { Acpt. / } \\
\text { Reject } \\
\text { Ho } \\
\end{array}$ \\
\hline Production related & 1.806 & 0.274 & Acpt. \\
\hline Shortage of labor & 4.845 & 0.181 & Acpt. \\
\hline $\begin{array}{c}\text { Lack of fertilizer and } \\
\text { pesticides }\end{array}$ & 5.685 & 0.104 & Acpt. \\
\hline Lack of technical know how & 2.502 & 0.514 & Acpt. \\
\hline Lack of irrigation facilities & 0.966 & 0.817 & Acpt. \\
\hline $\begin{array}{c}\text { Lack of equipment and } \\
\text { machinery }\end{array}$ & 4.607 & 0.207 & Acpt. \\
\hline $\begin{array}{c}\text { Lack of improved and high } \\
\text { yielding varieties }\end{array}$ & 5.223 & 0.144 & Acpt. \\
\hline Marketing related & 1.714 & 0.657 & Acpt. \\
\hline Middlemen interference & 1.277 & 0.735 & Acpt. \\
\hline $\begin{array}{c}\text { Lack of market information } \\
\text { (price, demand etc.) }\end{array}$ & 4.058 & 0.273 & Acpt. \\
\hline Lack of storage facilities & 3.006 & 0.427 & Acpt. \\
\hline $\begin{array}{c}\text { Lack of appropriate market } \\
\text { facilities }\end{array}$ & 1.684 & 0.662 & Acpt. \\
\hline $\begin{array}{l}\text { Malpractices in selling } \\
\text { (grading, weighing etc.) }\end{array}$ & 6.477 & 0.048 & Acpt. \\
\hline $\begin{array}{c}\text { Inadequate minimum } \\
\text { support price }\end{array}$ & 6.674 & 0.037 & Acpt. \\
\hline Finance related & 5.115 & 0.154 & Acpt. \\
\hline $\begin{array}{c}\text { Lack of sufficient } \\
\text { availability of credit } \\
\text { facilities }\end{array}$ & 3.470 & 0.355 & Acpt. \\
\hline $\begin{array}{c}\text { Lack of finance at } \\
\text { reasonable rate of interest }\end{array}$ & 2.024 & 0.600 & Acpt. \\
\hline Delay in cash payment & 1.460 & 0.703 & Acpt. \\
\hline
\end{tabular}

Source: Investigation

In the above table: 02, we can find out the relation between age and problems faced by the farmers in Andra Pradesh. Farmers are facing problems related to production, marketing, and finance, chi-square test was applied to find out the problems age-wise in the Andhra Pradesh, we can find out values and Relationship between age and problems faced by the farmers in Andhra Pradesh State in the above table. significant at 5\% level and significant at $1 \%$ level Lack of finance at a reasonable rate of interest was rejected. The farmers are having many finance-related problems.

Table 3. Education

\begin{tabular}{|c|c|c|}
\hline \multicolumn{3}{|c|}{ Education al Qualification } \\
\hline Classification & No. of Respondents & Percentage \\
\hline School Education & 122 & 48.8 \\
\hline Diploma/Degree & 79 & 31.6 \\
\hline Noformal Education & 49 & 19.6 \\
\hline Total & 250 & 100 \\
\hline
\end{tabular}

Source: Investigation

The above table:03 indicates farmers Educational Qualification, in this study $48.8 \%$ of respondents 
completed School Education Qualification and 31.6\% of respondents completed Diploma/Degree and $19.6 \%$ of respondents not completed Formal Education respectively. Here we can understand above maximum all farmers are educated and have been working in the agricultural sector.

Table 4. Relationship between Educational Qualification and problems faced by the farmers in Andhra Pradesh State

\begin{tabular}{|c|c|c|c|}
\hline $\begin{array}{c}\text { Problems Faced by the } \\
\text { Farmers }\end{array}$ & $\begin{array}{c}\mathbf{X}^{2} \\
\text { Value }\end{array}$ & $\mathbf{P}$-Value & $\begin{array}{c}\text { Acpt. / } \\
\text { Reject } \\
\text { Ho }\end{array}$ \\
\hline Production related & 10.414 & 0.12 & Acpt. \\
\hline Shortage of labour & 11.30 & 0.17 & Acpt. \\
\hline $\begin{array}{c}\text { Lack of fertilizer and } \\
\text { pesticides }\end{array}$ & 15.277 & 0.041 & Acpt. \\
\hline Lack of technical know how & 8.503 & 0.266 & Acpt. \\
\hline Lack of irrigation facilities & 6.406 & 0.48 & Acpt. \\
\hline $\begin{array}{c}\text { Lack of equipment and } \\
\text { machinery }\end{array}$ & 5.433 & 0.587 & Acpt. \\
\hline $\begin{array}{c}\text { Lack of improved and high } \\
\text { yielding varieties }\end{array}$ & 8.520 & 0.263 & Acpt. \\
\hline Marketing related & 8.071 & 0.305 & Acpt. \\
\hline Middlemen interference & 11.085 & 0.085 & Acpt. \\
\hline $\begin{array}{c}\text { Lack of market information } \\
\text { (price, demand etc.) }\end{array}$ & 4.376 & 0.701 & Acpt. \\
\hline Lack of storage facilities & 10.843 & 0.113 & Acpt. \\
\hline $\begin{array}{c}\text { Lack of appropriate market } \\
\text { facilities }\end{array}$ & 9.45 & 0.186 & Acpt. \\
\hline $\begin{array}{c}\text { Malpractices in selling } \\
\text { grading, weighing etc.) }\end{array}$ & 6.201 & 0.501 & Acpt. \\
\hline $\begin{array}{c}\text { Inadequate minimum support } \\
\text { price }\end{array}$ & 3.731 & 0.761 & Acpt. \\
\hline $\begin{array}{c}\text { Finance related } \\
\text { of credit facilities }\end{array}$ & 10.102 & 0.17 & Acpt. \\
\hline $\begin{array}{c}\text { Lack of finance at reasonable } \\
\text { rate of interest }\end{array}$ & 22.717 & $0.003 * *$ & Rej \\
\hline Delay in cash payment & 3.138 & 0.807 & Acpt. \\
\hline
\end{tabular}

Source: Investigation

In the above table: 04, we can find out the relation between qualification and problems faced by the farmers in Andra Pradesh. Farmers are facing problems related to Production, marketing, and finance, the chi-square test was applied to find out the problems qualification wise in the Andhra Pradesh, we can find out values and Relationship between qualification and problems faced by the farmers in Andhra Pradesh State in the above table, significant at $5 \%$ level and significant at $1 \%$ level Lack of sufficient availability of credit facilities and Lack of finance at a reasonable rate of interest were rejected. The farmers are having many finance-related problems.
Table 5. Source of income

\begin{tabular}{|c|c|c|}
\hline \multicolumn{3}{|c|}{ Source of Income } \\
\hline Classification & No. of Respondents & Percentage \\
\hline Agriculture alone & 179 & 71.6 \\
\hline $\begin{array}{c}\text { Business/ Service along with } \\
\text { agriculture }\end{array}$ & 71 & 28.4 \\
\hline Total & 250 & 100 \\
\hline
\end{tabular}

Source: Investigation

The above table: 05 indicates the Source of Income of farmers, in this study $71.6 \%$ of respondents are earning money from the agricultural sector only and $28.4 \%$ of respondents are earning income through Business/ Service along with agriculture respectively. Here we can understand the main source of income of farmers from the agricultural sector.

Table 6. Relationship between Source of income and problems faced by the farmers in Andhra Pradesh State

\begin{tabular}{|c|c|c|c|}
\hline $\begin{array}{l}\text { Problems Faced by the } \\
\text { Farmers }\end{array}$ & $\begin{array}{c}\mathrm{X}^{2} \\
\text { Value } \\
\end{array}$ & P -Value & $\begin{array}{c}\text { Acpt. / } \\
\text { Reject Ho }\end{array}$ \\
\hline Production related & 4.707 & 0.458 & Acpt. \\
\hline Shortage of labour & 5.686 & 0.335 & Acpt. \\
\hline $\begin{array}{l}\text { Lack of fertilizer and } \\
\text { pesticides }\end{array}$ & 2.077 & 0.801 & Acpt. \\
\hline $\begin{array}{c}\text { Lack of technical know } \\
\text { how }\end{array}$ & 1.273 & 0.856 & Acpt. \\
\hline $\begin{array}{l}\text { Lack of irrigation } \\
\text { facilities }\end{array}$ & 17.071 & $0.008 * *$ & Rej. \\
\hline $\begin{array}{c}\text { Lack of equipment and } \\
\text { machinery }\end{array}$ & 5.022 & 0.416 & Acpt. \\
\hline $\begin{array}{l}\text { Lack of improved and } \\
\text { high yielding varieties }\end{array}$ & 3.013 & 0.705 & Acpt. \\
\hline Marketing related & 9.522 & 0.131 & Acpt. \\
\hline Middlemen interference & 8.707 & 0.168 & Acpt. \\
\hline $\begin{array}{c}\text { Lack of market } \\
\text { information (price, } \\
\text { demand etc.) }\end{array}$ & 21.57 & $0.001 * *$ & Rej. \\
\hline Lack of storage facilities & 20.321 & $0.001 * *$ & Rej. \\
\hline $\begin{array}{c}\text { Lack of appropriate } \\
\text { market facilities }\end{array}$ & 13.886 & $0.02 *$ & Rej. \\
\hline $\begin{array}{l}\text { Malpractices in selling } \\
\text { (grading, weighing etc.) }\end{array}$ & 13.707 & $0.022^{*}$ & Rej. \\
\hline $\begin{array}{c}\text { Inadequate minimum } \\
\text { support price }\end{array}$ & 9.267 & 0.142 & Acpt. \\
\hline Finance related & 5.360 & 0.374 & Acpt. \\
\hline $\begin{array}{l}\text { Lack of sufficient } \\
\text { availability of credit } \\
\text { facilities }\end{array}$ & 9.306 & 0.141 & Acpt. \\
\hline $\begin{array}{l}\text { Lack of finance at } \\
\text { reasonable rate of interest }\end{array}$ & 13.766 & $0.021^{*}$ & Rej. \\
\hline Delay in cash payment & 6.822 & 0.316 & Acpt. \\
\hline
\end{tabular}

Source: Investigation 
In the table: 06, we can find out the relation between qualification and problems faced by the farmers in Andra Pradesh. Farmers are facing problems related to production, marketing, and finance, the chi-square test was applied to find out the problems qualification wise in Andhra Pradesh, we can find out values and Relationship between qualification and problems faced by the farmers in Andhra Pradesh State in the above table. significant at 5\% level and significant at 1\% level Lack of irrigation facilities, Lack of market information (price, demand etc.), Lack of storage facilities, Lack of appropriate market facilities, Malpractices in selling (grading, weighing etc.) and Lack of finance at a reasonable rate of interest was rejected.

From the tables 02,04 and 06 it is assumed that the respondents face a greater amount of the creation, showcasing and financing related issues like Lack of water system offices, Lack of market data (value, request and so forth), Lack of storerooms, Lack of suitable market offices, Malpractices in selling (reviewing, judging and so on) and Lack of money at the sensible pace of revenue

\section{Suggestions}

(1) A combination of town terrains and agreeable cultivating will facilitate the weight of divided landholdings. At the point when the farmers structure a consortium at the town level, the total land can be cultivated by utilizing the most recent innovation.

(2) The utilization of refined ranch hardware and gear will assist the minimal farmers with expanding agricultural profitability.

(3) To address the issue of production network bottlenecks, the public authority has begun controlling the market. Serious purchasing, disposal of acts of neglect, use of normalized loads and measures, improved question settlement framework is the pith of the system.

(4) The government should give low-intrigue credits and financed ranch machines to upgrade work profitability in cultivating and to decrease work issues.

(5) Crop protection is an unquestionable requirement for farmers to save them from cataclysmic events.

(6) The Government should fix the least costs for all wares including transitory vegetables like tomatoes and natural products to forestall trouble selling.

(7) Banks also will loan cash to a town the consortium which can be used to help ranch profitability, utilize manageably cultivating techniques, diminish overdependence on manures, and accordingly take care of numerous issues.

(8) Irrigation issues can be tended to by Government ideally at the State and National levels. In spite of the fact that the Government can't compel farmers to deliver just the assigned yields specifically territories, it can definitely instruct them about the other options.

(9) Scientific examination in this the subject is to be urged to advance seeds which are gentle on asset necessities however, help the farmers in boosting the yields.

(10) Some manageability arrangements are appropriate to harvest the board based on water accessibility, crop revolution, conveying current agricultural practices to support efficiency, exchanging over to natural cultivating push on unified exercises.

(11) Storage offices can be helped by little chilly stockpiling or silos at the town level which can be set up from Panchayat assets and credits to the town society.

\section{Conclusions}

There is no uncertainty that in any advertising there is a rationale towards benefit included and simultaneously, the promoting is to be founded on specific qualities, standards, and methods of reasoning, for example, offering just and reasonable costs to the farmers who work hard to work. Bringing fundamental changes combined with appropriate value revelation components through a controlled market framework will help smooth out and reinforce agricultural promoting. In case the party and incorporation efforts are taken from various areas by producers, mediators, experts and chairmen, the promotions of horticulture can be improved. It's about time that we brought out critical methodologies in agricultural advertising with imaginative and inventive ways to deal with carry products of work to the farmers.

\section{REFERENCES}

[1] Chahal, S.S. and Kataria, P. 2010. Constraints in the production and marketing of maize in Punjab. Agric. Update, Volume 5(1\&2): 228-236.

[2] Kumari, M., Meena, L.K. and Singh, R.G. 2015. Problems and prospects of maize crop in eastern zone of Bihar. Int. J. of Agril. Sc., Volume-5 Issue-2: 138-146.

[3] Rajesh, R. and Sundaresan, R. 2002. Marketing Decision by Farmers and their Operational Constraints. Encycl. Agril. Mktg., Volume-3: 269-82.

[4] A.D. Siyoum Broken Promises (Food Security Interventions and Rural Livelihoods in Ethiopia), Disaster Studies Wageningen University. Promotor(en): Thea Hilhorst, co-promotor(en): A. Pankhurst; Gerrit-Jan van Uffelen. S.l. : s.n. - ISBN 9789461733665 - p. 172.

[5] Addisu Karafo (2017). Role of Equb in Financing Micro and Small Business Enterprises in Konso. Universal Journal of Accounting and Finance, 5(1), 1 - 8. DOI: 10.13189/ujaf.2017.050101. 
[6] M. Kassie, P. Zikhali, K. Manjur, S. Edwards Adoption of sustainable agriculture practices: evidence from a semi-arid region of Ethiopia Nat. Resour. Forum. First published: 29 September 2009 https://doi.org/10.1111/j.14778947.2009.0 1224.x (Wiley Online Library)

[7] Ramkishen, Y. (New Edition) 2004. New Perspectives in Rural and Agricultural marketing. Jaico Publications, Mumbai, India. September 2004 (Book)
[8] Ramesh, S.V. 2014. Cotton cultivation and marketing- a study on prospects and problems in Tirupur district. Int. J. Ent. Innov. Mgmt. Studies, Volume-1, Issue-3: 81-88.

[9] Ateyah Mohammad Alawneh (2019). Effect of Net Cash Flows on Investors' Decisions on Companies Listed in Amman Stock Exchange during the Period of 2001-2017: A Case Study on Industry and Service Sectors. Universal Journal of Accounting and Finance, 7(2), 50 - 65. DOI: 10.13189/ujaf.2019.070203. 